\title{
The Influence of Particle Size and Fuel Consumption Rate on Oil Characteristics from Pyrolysis of Aluminum Foil Coated Polyethylene (Al-PE) Waste
}

\author{
M. Noviansyah Aridito \\ Universitas Proklamasi 45 \\ Email: noviansyaharidito@up45.ac.id
}

\begin{abstract}
The collection of oil and aluminum is an effort made in order to utilize waste from Aluminum Foil Coated Polyethylene (Al-PE). Meanwhile, pyrolysis is one of the conversion technologies that can be used to treat this waste. The materials that would be used in this research is Al-PE plastic waste. This research aims to determine the effect of fuel consumption rate and particle size on the oil characteristics from pyrolysis of aluminum foil coated polyethylene plastic (AI-pE) waste. The material used in this research is Al-PE plastic waste. The selected particle size variations were $50 \times 50 \mathrm{~mm}$ and $100 \times 100 \mathrm{~mm}$ for 130 minutes with variations in fuel consumption rate of $4.77 \mathrm{~g} / \mathrm{min}, 377 \mathrm{~g} / \mathrm{min}$ and $2.46 \mathrm{~g} / \mathrm{min}$. The resultant pyrolysis and aluminum oil is measured to obtain yield. The results showed that Al-PE pyrolysis oil has a brownish yellow color, distinctive odor, flammability and physical character close to kerosene even to gasoline. The oil yield is between $6.9 \%$ wt to $22.4 \%$ wt. The highest oil yield and highest heating value obtained from sample A with particle size $50 \times 50 \mathrm{~mm}$ and fuel consumption rate $4.99 \mathrm{~g} / \mathrm{min}(0.29 \mathrm{~kg} / \mathrm{h}) \mathrm{per}$ $\mathrm{kg}$ of Al-PE for $130 \mathrm{~min}$ with material density in reactor $27 \mathrm{~kg} / \mathrm{m} 3$.
\end{abstract}

Keywords: Pyrolysis, Al-PE, heating rate, particle size

\section{Introduction}

Plastic as a kind of solid waste is difficult to decompose and at the same time, its volume continues to increase every year. Due to the prices, practicality, and flexibility of use, the plastics have more advantages than other materials, such as; lighter, insulators, hard to decompose and cheap in production prices [1]. In addition, population growth, lifestyle and increased of packaging products consumption also trigger the increase in the volume of waste plastic. Data from the Deputy of Pollution Control of State Ministry of 
Environment [2] stated that each of the average society produces $0.8 \mathrm{~kg}$ of garbage and $15 \%$ is the plastic waste. The estimated amount of plastic waste from 240 million population of Indonesia is 28,800 Ton/day. The amount of plastic waste will continue to grow and will be a potential threat to the environment and human sustainability in the future.

Plastic is one type of polymer which generally use basic materials such as polypropylene (PP), polyethylene (PE), polystyrene (PS), poly methyl methacrylate (PMMA), high-density polyethylene (HDPE) and polyvinyl chloride (PVC). Up until now, plastic is still a material used by industry and households widely. Meanwhile, the most common type of plastic used in the community for aluminum foil-coated packaging is Polyethylene (PE). To do the calculation, the polyethylene chemical formula is (-CH2-) $n, n$ is the degree of polymerization [3].

The formation reaction is as follows:

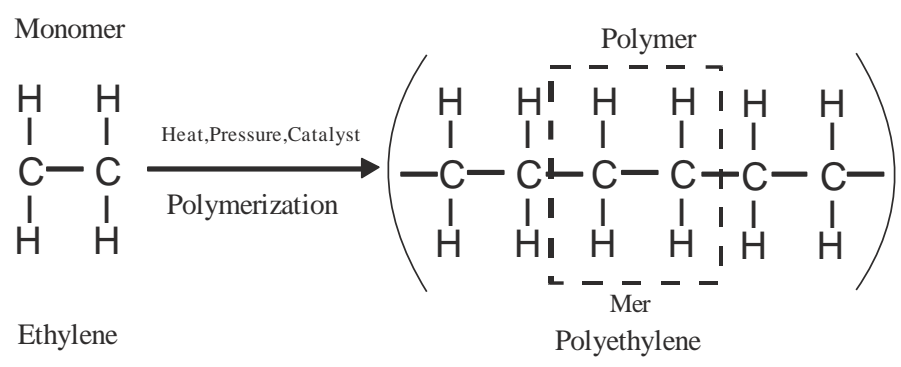

Figure 1. Polyethylene Formation Process

Some types of plastics can be recycled into plastic ores, but aluminum foil-coated plastic waste can not be processed with that technology. Based on the facts found in the field, both from studies/surveys and newspapers show that the garbage is not well managed by the authorities so it becomes an environmental issue. The aluminum foil coating of this type prevents it from being recycled as a pellet/plastic ore product. This condition causes aluminum foil coated plastic waste is not economical and pollute the environment, which makes this type of waste only piled up in various places or burned carelessly.

The removal of plastic waste using a burning method can create a dangerous pollutant. Landfill and open dumping methods in the final disposal site are no longer possible with the growing consumption of plastic packaging that continues to increase, while the plastics require a very long time to decompose. The disposal by burning process (incineration) risks generating pollutants from exhaust emissions ie $\mathrm{CO} 2, \mathrm{CO}, \mathrm{NOx}, \mathrm{HCN}, \mathrm{SOx}$ and some other pollutant particulates. The finalization process of waste or plastic waste has not supported the concept of sustainable development (sustainable development).

Alternatives to the process of recycling plastic waste that can not be processed into plastic ores can be carried out by the following processes; pyrolysis, hydrocracking, and hydrogenation processes [1]. The pyrolysis 
process is one option to recycle the polyethylene plastic waste with coated aluminum foil. The expected pyrolysis product is plastic oil, which can be used as an alternative fuel. Further processed plastic oil is expected to be an alternative fuel for combustion engines so it can be more useful.

Pyrolysis is the process of decomposition of a material at high temperatures in the absence of air or with limited air. The decomposition process in pyrolysis is also often called devolatilization. The main products of pyrolysis that can be produced are charcoal, oil, and gas. The formed charcoal can be used for fuel or as activated carbon and the resulting oil can be used as an additive or mixture in the fuel, while the formed gas can be burned directly [4]. Purwanti and Sumarni [3] have pyrolyzed LDPE plastic pieces with pyrolysis operating temperatures ranging from $400^{\circ} \mathrm{C}-600^{\circ} \mathrm{C}$. The amount of the product is directly proportional to the temperature rise as well as the length of the process. The amount of solid or charcoal will be less with the increase in temperature and processing time. The effects of temperature and rate of warming on slow pyrolysis have been investigated by Williams [5], the heating rate used is between $5^{\circ} \mathrm{C} / \min$ and $80^{\circ} \mathrm{C} / \mathrm{min}$ with temperatures of $300^{\circ} \mathrm{C}$ and $750^{\circ} \mathrm{C}$.

The pyrolysis process will produce condensed fumes called plastic oil and charcoal solids left in the reactor. Factors that may affect the process of pyrolysis are [6], [4], [7] The analysis of the physical properties of pyrolysis oils includes analysis of specific gravity, heat value, flash point, por point, and kinematic viscosity [8], [9], [10].

\section{Materials and Methods}

\subsection{Research Locations}

The research was conducted in Trayeman, Pleret, Bantul, Yogyakarta, CV. Harimukti Teknik, including design work, assembling tools and process of pyrolysis Al-PE. Testing of the characteristics of pyrolysis oil was conducted at the Petroleum, Coal and Gas Chemical Engineering Laboratory at UGM which has been cultivated ISO 17025: 2005.

\subsection{Flowchart}

The picture below presents the research flow diagram:

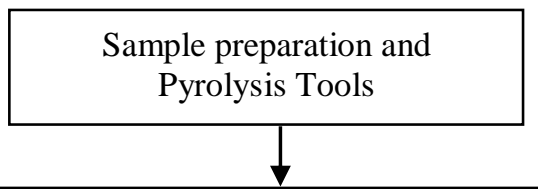

Plastic pyrolysis coated aluminum foil, cleaning process and chopping size at 50 $\times 50 \mathrm{~mm}, 100 \times 100 \mathrm{~mm}$, Pyrolysis for 130 minutes with warious of fuel consumption rate. 


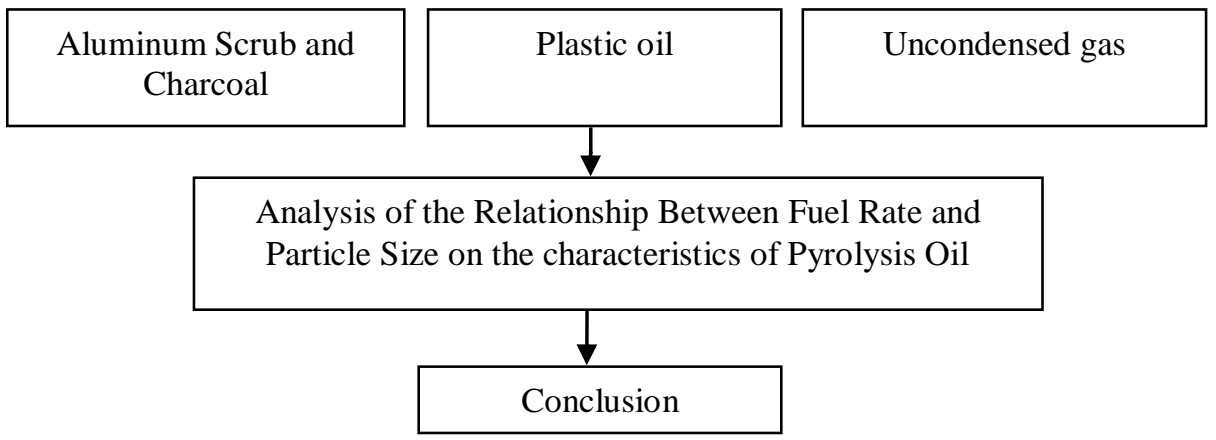

Figure 2. Research Flowchart

\subsection{Research Materials}

The raw material used in this research is aluminum foil-coated polyethylene waste from Final Disposal Site (TPA) in Piyungan, Bantul Yogyakarta and the water used in this research has a function as a coolant on the condenser.

\subsection{Research Tools}

The tools used in this research include $250 \mathrm{ml}$ measuring cylinders, stopwatch, glass bottles, one unit pyrolysis batch system capacity of 1000 grams of plastic. The pyrolysis reactor that has been used in this research is a prototype reactor with a diameter of $40 \mathrm{~cm}$ and a height of $30 \mathrm{~cm}$. The length of the condenser is 1.5 meters and its diameter is 1 inch. The length of the outer tube of the reactor is 1.25 meters and 3 inches in diameter, while the pump used is a water pump with a discharge of $1 \mathrm{~m} 3 / \mathrm{h}$. A separator device is installed at the end of the condenser to separate the oil product and the noncondensable gas. A separator is installed to connect the gas output with a gas reservoir made of polypropylene plastic measuring $55 \mathrm{~cm} \times 150 \mathrm{~cm}$

Explanation:
1. Heater
2. Pyrolysis reactor
3. Condenser
4. Separator
5. Gas container
6. Oil container
7. Water reservoir
8. Water pump
T = Thermometer

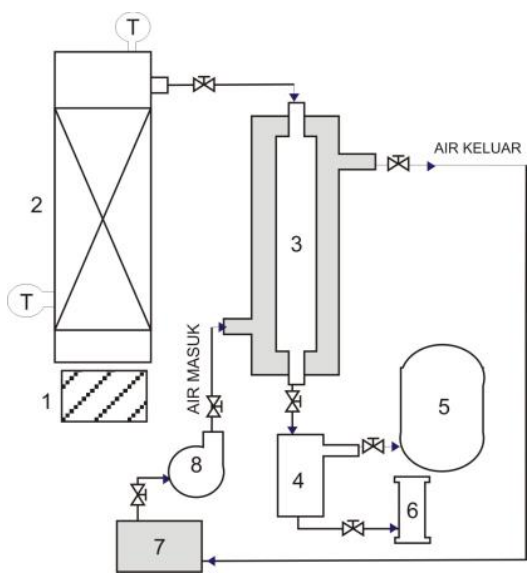

Figure 3. Scheme of pyrolysis tools 


\subsection{Research procedure}

\subsubsection{Preparation}

Raw materials still in the form of aluminum foil-coated polyethylene plastic waste are cleaned to minimize impurities. This material is cut to size $50 \times 50 \mathrm{~mm}$ and $100 \times 100 \mathrm{~mm}$, then measuring cups are prepared to accommodate pyrolysis oil. Water is prepared for the condenser and proceeds in the cooling basin.

\subsubsection{Phase of pyrolysis process}

Aluminum foil coated plastic that has been cleaned as much as $1000 \mathrm{~g}$ with size $50 \times 50 \mathrm{~mm}$ placed into the pyrolysis reactor. In preparation, the nuts and bolts must be sealed carefully to prevent a gas leak. Then, the reactor is coated with silicon with the temperature set at $450^{\circ} \mathrm{C}$. The pyrolysis process lasted for 130 minutes with an average fuel consumption

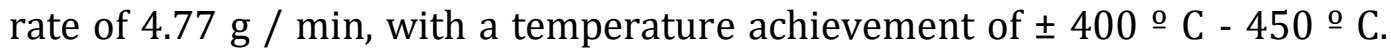
This temperature is maintained until the entire process is over and the pyrolysis oil is then collected in a measuring cup.

The next experiment was carried out on materials measuring $100 \times 100$ $\mathrm{mm}$ with a consumption rate of $4.77 \mathrm{~g} / \mathrm{min}$. Then with the same procedure, the experiment was carried out again on materials measuring $50 \times 50 \mathrm{~mm}$ and $100 \times 100 \mathrm{~mm}$ with a variation of fuel consumption rate of $2.46 \mathrm{~g} / \mathrm{min}$.

The control variables in this research were at the time of pyrolysis; $130 \mathrm{~min}$ and the mass of Al-PE waste plastic waste; 1000 gram. Process variables (treatment) in this research is the size pyrolyzed Al-PE plastic of 50 $\mathrm{mm} \times 50 \mathrm{~mm}$ and $100 \mathrm{~mm} \times 100 \mathrm{~mm}$. Another process variable is the heating (valve) using the control valve (valve) of the gas set at; maximum (100\%), with a fuel consumption rate of $4.77 \mathrm{~g} / \mathrm{min}$, moderate $(75 \%)$ with a fuel consumption rate of $3.77 \mathrm{~g} \mathrm{/} \mathrm{min,} \mathrm{and} \mathrm{minimum} \mathrm{(50 \% )} \mathrm{with} \mathrm{a} \mathrm{fuel}$ consumption rate of $2.46 \mathrm{~g} / \mathrm{min}$.

\begin{tabular}{llcl}
\hline \multicolumn{1}{c}{ Control } & \multicolumn{2}{c}{ Process } & Sample \\
\cline { 2 - 3 } & Particle Size $\mathbf{( m m )}$ & $\begin{array}{c}\text { Fuel } \\
\text { consumption } \\
\text { rate (g/minute) }\end{array}$ & \\
\hline $\begin{array}{l}\text { Pyrolysis reactors } \\
\text { dimension }\end{array}$ & $50 \times 50$ & 4,77 & Sample A \\
$\begin{array}{l}130 \text { minutes } \\
\text { The mass of AL-PE is } 100\end{array}$ & $50 \times 50$ & 3,77 & Sample B \\
grams & $50 \times 50$ & 2,46 & Sample C \\
Density of $0,035 \mathrm{~g} / \mathrm{cm}^{3}$ & $100 \times 100$ & 4,77 & Sample D \\
& $100 \times 100$ & 2,46 & Sample E \\
\hline
\end{tabular}

Table 1. Varibel Bebas Penelitian 
Results evaluation in this study, include:

1. Calculation of yield of oil produced $(\mathrm{ml} / \mathrm{g})$

$$
\text { Yield }\left(\frac{\mathrm{ml}}{\mathrm{g}}\right)=\frac{\text { Volume of pyrolysis oil }}{\text { mass of plastic }}
$$

2. Calculation of aluminum $(\mathrm{mg} / \mathrm{g})$

$$
\text { Yield }\left(\frac{m g}{g}\right)=\frac{\text { mamass of pyrolysis of aluminum }}{\text { mass of plastic }}
$$

3. Tests on the characteristics of pyrolysis oil include specific gravity, gross heating value, kinematic viscosity, flash point, pour point and water content and aluminum rendement which includes microstructure.

\section{Results and Discussion}

\subsection{Characteristics of Reactors and Research Variables}

The pyrolysis reactor used in this research is prototype reactor with diameter $40 \mathrm{~cm}$ and height $30 \mathrm{~cm}$, condenser length 1.5 meter with the 1 inch diameter, while the length of the outer tube is 1.25 meter with the 3 -inch diameter. The water pump is a very important tool for the flow of cooling water with a discharge of $1 \mathrm{~m} 3 / \mathrm{h}$. The separator is deliberately installed on the end of the condenser to separate between the non-condensable oil and gas products. Meanwhile, for gas output, the separator end is connected to a gas container made of polypropylene plastic measuring $55 \mathrm{~cm} \times 150 \mathrm{~cm}$.

The AI-LE material of 1000 grams was then placed into a pyrolysis reactor with an Al-PE plastic density dimension in an average $0.027 \mathrm{~g} / \mathrm{cm} 3$ pyrolysis reactor. During the pyrolysis process, the temperature changes are recorded for 130 minutes and temperature changes in oil and gas products are observed and recorded every 10 minutes.

\subsection{Results and Characterization of Al-PE Plastic Wastewater pyrolysis}

This research will measure the following variables: process temperature, volume, and yield of Al-PE pyrolysis oil, oil characteristics.

\subsubsection{Temperature Profile}

Gambar 4.1 menyajikan profil dari suhu proses pirolisis atas sampah plastik Al-PE, bukaan valve (laju konsumsi bahan bakar) dan suhu. 


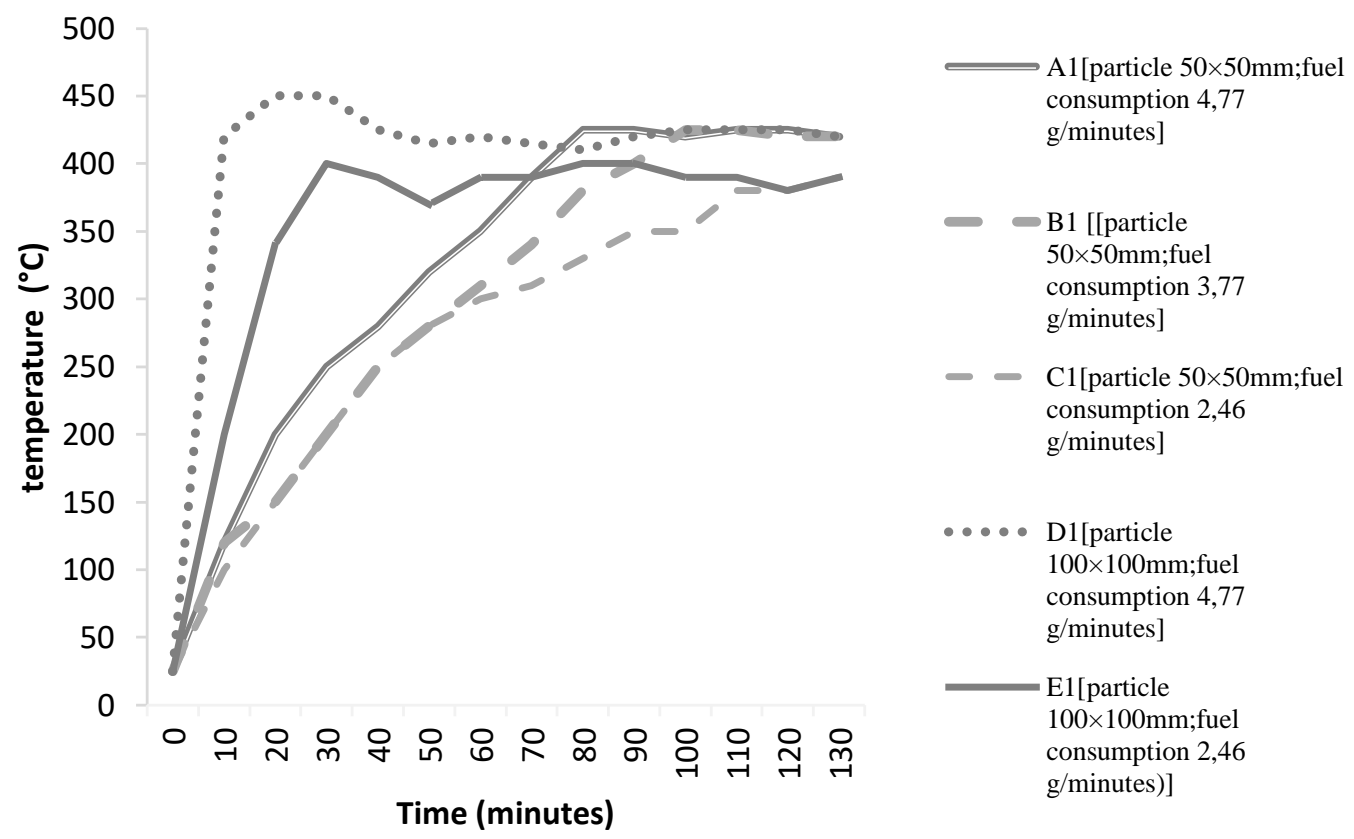

Figure 4. Pirolysis Temperature Profile

As shown in Figure 4, the peak temperatures achieved by each process are varied. In addition, there was a time difference to reach the peak temperature at each treatment sample showing the difference in heating rate. The A1 sample reached a peak temperature of $425^{\circ} \mathrm{C}$ within 80 minutes, then the temperature was relatively stable until the 130th minute (holding time). Sample B1 has reached a peak temperature of $425^{\circ} \mathrm{C}$ within 100 minutes. The $\mathrm{C} 1$ sample reached a peak temperature of $390^{\circ} \mathrm{C}$ within 130 minutes. The D1 sample takes about 20 minutes to reach the peak temperature, but the temperature drop occurs up to $425^{\circ} \mathrm{C}$ and then relatively stable at $420^{\circ} \mathrm{C}-430^{\circ} \mathrm{C}$ until the 130 th minute. The sample E1 has reached a peak temperature of $400 \mathrm{C}$ and takes about 60 minutes. The peak temperature and the heating rate of the pyrolysis process for samples $\mathrm{A}, \mathrm{B}, \mathrm{C}$, $\mathrm{D}$, and E respectively are $450{ }^{\circ} \mathrm{C} ; 5,3125{ }^{\circ} \mathrm{C} / \mathrm{min}, 425{ }^{\circ} \mathrm{C} ; 4.25{ }^{\circ} \mathrm{C} / \mathrm{min}, 425$ ${ }^{\circ} \mathrm{C} ; 3{ }^{\circ} \mathrm{C} / \mathrm{min}, 450{ }^{\circ} \mathrm{C} ; 22.5{ }^{\circ} \mathrm{C} / \mathrm{min}$, and $450{ }^{\circ} \mathrm{C} ; 13,333^{\circ} \mathrm{C} / \mathrm{min}$. The following table shows the relationship of peak temperature, time and rate of heating namely:

\begin{tabular}{lccclcc}
\hline Sample & $\begin{array}{l}\text { Peak } \\
\text { Temperature } \\
\left({ }^{\circ} \mathrm{C}\right)\end{array}$ & $\begin{array}{l}\text { Time } \\
\text { (minutes) }\end{array}$ & $\begin{array}{l}\text { Holding } \\
\text { time } \\
\text { (menit) }\end{array}$ & $\begin{array}{l}\text { Fuel } \\
\text { consumption } \\
\text { rate (g / } \\
\text { min) }\end{array}$ & $\begin{array}{l}\text { Heating } \\
\text { rate } \\
\left({ }^{\circ} \mathrm{C} /\right. \\
\text { min) }\end{array}$ & $\begin{array}{l}\text { formed } \\
\text { oil in } \\
\text { the } \\
\text { minutes } \\
\text { of- }\end{array}$ \\
\hline $\begin{array}{l}\text { Sample } \\
\begin{array}{l}\text { A1 } \\
\text { Sample }\end{array}\end{array}$ & 425 & 80 & 50 & 4,77 & & 10 \\
B1 $^{*}$ & 425 & 100 & 30 & 3,77 & 5,31 & 10 \\
\hline
\end{tabular}




\begin{tabular}{lcccccc}
\hline Sample & 390 & 130 & 0 & 2,46 & & 30 \\
C1* & & & & & 3,00 & \\
$\begin{array}{l}\text { Sample } \\
\text { D1** }\end{array}$ & 450 & 20 & 110 & 3,77 & & 20 \\
$\begin{array}{l}\text { Sample } \\
\text { E1** }\end{array}$ & 400 & 40 & 90 & 2,46 & 22,50 & 30 \\
\hline
\end{tabular}

* = Sample particle size A1, B1, C1 is $\pm 50 \times 50 \mathrm{~mm}$

** = Particle size D1 and E1 is $>100 \times 100 \mathrm{~mm}$

Table 2. Profile of peak temperature, time and rate of heating

When compared to the same particle size between A1, B1, and C1 it appears that $\mathrm{A} 1$ has the highest heating rate. And if D1 and E1 are compared, it would appear D1 has a higher heating rate. This is because the treatment of heat energy in sample A1 is greater than B1 and C1, and D1 is larger than E1.

Based on the overall result the D1 sample has the highest heating rate and the $\mathrm{C} 1$ sample has the lowest heating rate. When compared on the basis of particle size, samples with smaller particle sizes tend to be relatively lower heating rates than larger particle sizes. In graph 4.1 the sample D1 and E1 rapidly reach the peak temperature but then decrease until the temperature is stable.

The size of the particles D1 and E1, which are larger than the other affects the gas temperature and cracking process in the pyrolysis reactor, resulting in a drastic increase in temperature but in the same minute, no oil has yet formed. This is obtained after duplicating the process on a smaller sample. In the D1 sample, in the 0th minute until the 20th minute, there is only dense white gas in larger quantities when compared to the A1 sample process that has produced the first oil droplets. Based on observations, oil formation in samples having the same particle size and having different heating rates indicates faster oil formation ie in samples with higher heating rates. The formation of oils on samples with smaller particle sizes produced faster activity than larger particle size samples.

\subsubsection{Volume and Yield measurement results}

The yield and volume of oil obtained in this research have shown different results in each treatment (sample). The following is the volume of $\mathrm{v}$ / wo (ml / g) and yield (wt \%) of pyrolysis oils on Al-PE plastics as shown in Table 3. 


\begin{tabular}{|c|c|c|c|c|c|c|}
\hline \multirow{2}{*}{\multicolumn{2}{|c|}{$\begin{array}{l}\text { No } \\
\text { Volume v (ml) }\end{array}$}} & \multirow{2}{*}{ Sample A } & \multirow{2}{*}{ Sample B } & \multirow{2}{*}{ Sample C } & \multirow{2}{*}{ Sample D } & \multirow{2}{*}{ Sample E } \\
\hline & & & & & & \\
\hline 1 & $\mathrm{P} 1$ & 279 & 235 & 96 & 209 & 90 \\
\hline \multirow[t]{2}{*}{2} & $\mathrm{P} 2$ & 303 & 225 & 117 & 229 & 83 \\
\hline & Average & 291 & 230 & 106 & 219 & 86 \\
\hline \multicolumn{7}{|c|}{$\mathrm{v} / \mathrm{w}_{0}(\mathrm{ml} / \mathrm{g})$} \\
\hline 1 & $\mathrm{P} 1$ & 0,279 & 0,235 & 0,096 & 0,209 & 0,090 \\
\hline \multirow[t]{2}{*}{2} & P2 & 0,303 & 0,225 & 0,117 & 0,229 & 0,083 \\
\hline & Average & 0,291 & 0,230 & 0,106 & 0,219 & 0,086 \\
\hline \multicolumn{7}{|c|}{ Massa wt (g) } \\
\hline 1 & $\mathrm{P} 1$ & 215 & 181 & 75 & 167 & 72 \\
\hline \multirow[t]{2}{*}{2} & P2 & 233 & 173 & 91 & 183 & 66 \\
\hline & Average & 224 & 177 & 83 & 175 & 69 \\
\hline \multicolumn{7}{|c|}{ Yield (wt\%) } \\
\hline 1 & P1 & 21,5 & 18,1 & 7,5 & 16,7 & 7,2 \\
\hline \multirow[t]{2}{*}{2} & P2 & 23,3 & 17,3 & 9,1 & 18,3 & 6,6 \\
\hline & Average & 22,4 & 17,7 & 8,3 & 17,5 & 6,9 \\
\hline
\end{tabular}

$$
\text { yield }=\frac{w_{t}}{w_{0}} ; \mathrm{w}_{0}=1000 \mathrm{~g}
$$

Table 3. volume and yield of pyrolysis oils on Al-PE plastic waste

Based on the data obtained in Table 2, the comparison between samples $A, B$, and $C$ with the same particle size but having different heating rates; shows that sample $A$ with higher heating rate produced a larger oil volume of $291 \mathrm{ml}$, when compared to samples production on samples B and C with $230 \mathrm{ml}$ and $106 \mathrm{ml}$. Similarly, samples with $100 \times 100 \mathrm{~mm}$ particle size on sample D1 with higher heating rates than E1, resulted in the higher volume of oil. If the observations were conducted by the same heat but with different particle sizes between samples $A$ and $D$, then the average oil yield on sample A was higher than sample D. Overall conslussion, the pyrolysis process in sample A yielded the greatest amount of oil.

The oil yield ratio produced by each sample is relatively the same as the volume. The yields of sample A, B, C, D, and E were $22.4 \%, 17.7 \%, 8.3 \%$, $17.5 \%$ and $6.9 \%$, respectively. The highest yield is produced in the sample $\mathrm{A}$ pyrolysis process with the smaller particle size and the higher rate of heating than others.

\subsubsection{Physical Characteristics}

Physical differences in viscosity and color are also seen in each process. Oil in samples A, B, C with particle sizes of materials of $50 \times 50 \mathrm{~mm}$ tends to be clearer and yellower than oils of a material particle size of $100 \times$ $100 \mathrm{~mm}$. The odor generated is also relatively similar, but the oils in samples 
A, B, C are more flammable than samples D and E. In addition, the oils in the D and $\mathrm{E}$ samples leave more soot after burning.

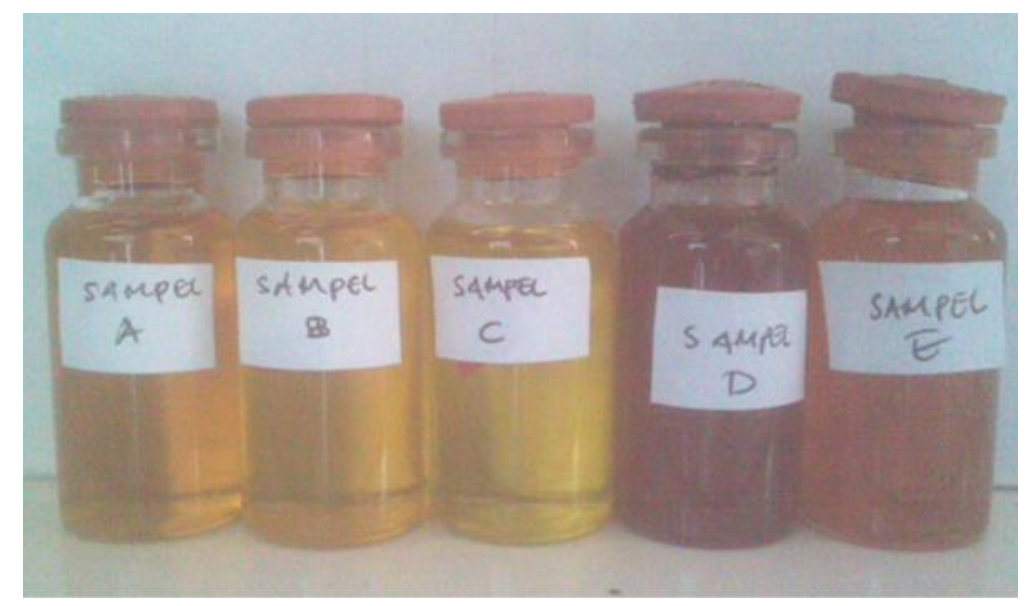

Figure 5. Oil pyrolysis results from left to right (samples A, B, C, D, E)

Other physical differences are seen in the residual solids of pyrolysis. The residual solids in the pyrolysis reactor of each process have shown differences. The difference can be observed physically from the level of purity of aluminum foil. The pyrolysis residual solid product is presented in Figure 6.

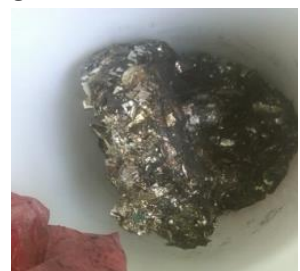

Sampel A

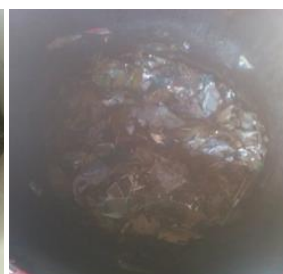

Sampel B

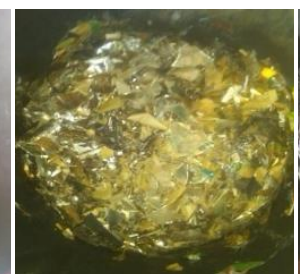

Sampel C

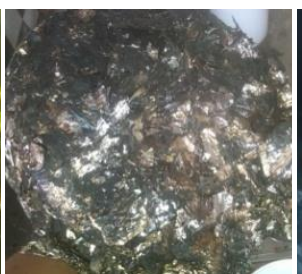

Sampel D

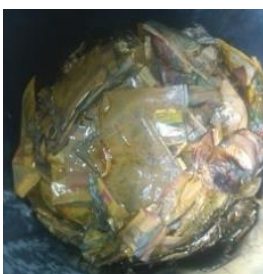

Sampel E

Figure 6. Rendement of the remaining plastic pyrolysis of Al-PE

Based on the pyrolysis results, the process of sample A has produced a cleaner residual solid than any other process. The $\mathrm{C}$ and $\mathrm{E}$ processes where the maximum temperature and the lowest heating rate produced the residual solids that still contain wax and plastic. This indicates that there are still many ingredients that have not yet undergone in a pyrolysis process. When compared to processes $\mathrm{A}$ and $\mathrm{D}$, the solids from process $\mathrm{D}$ are much dirtier because they still leave much more carbon in the aluminum foil. Analyzed from the residual pyrolysis solids, the pyrolysis process over sample A has resulted in a cleaner residual solid, making it easier in the aluminum purification process.

The results of pyrolysis oil are analyzed qualitatively on the basis of their physical characteristics. Table 4 . shows the physical characteristics of the oil products of each process. 


\begin{tabular}{|c|c|c|c|c|c|c|c|c|}
\hline \multirow[t]{2}{*}{ No } & \multirow{2}{*}{$\begin{array}{l}\text { Type of } \\
\text { Examination }\end{array}$} & \multirow[t]{2}{*}{ Unit } & \multicolumn{5}{|c|}{ Results of Plastic Pyrolysis Examination } & \multirow{2}{*}{$\begin{array}{l}\text { Examinatio } \\
n \text { methods }\end{array}$} \\
\hline & & & $\begin{array}{l}\text { Sampl } \\
\text { e A }\end{array}$ & $\begin{array}{l}\text { Sampl } \\
\text { e B }\end{array}$ & $\begin{array}{l}\text { Sampl } \\
\text { e C }\end{array}$ & $\begin{array}{l}\text { Sampl } \\
\text { e D }\end{array}$ & $\begin{array}{l}\text { Sampl } \\
\text { e E }\end{array}$ & \\
\hline \multirow[t]{2}{*}{1} & Specific & - & 0,7651 & 0,770 & 0,772 & 0,794 & 0,798 & ASTM D \\
\hline & $\begin{array}{l}\text { Gravity at } \\
60 / 60^{\circ} \mathrm{F}\end{array}$ & & & 5 & 4 & 8 & 7 & 1298 \\
\hline 2 & $\begin{array}{l}\text { Viscosity } \\
\text { Kinematic at } \\
40{ }^{\circ} \mathrm{C}\end{array}$ & $\begin{array}{l}\mathrm{mm}^{2} / \\
\mathrm{s}\end{array}$ & 0.667 & 0,692 & 0,700 & 0,861 & 1,064 & $\begin{array}{l}\mathrm{IKU} / 5.4 / \mathrm{T} \\
\mathrm{K}-02\end{array}$ \\
\hline 3 & $\begin{array}{l}\text { Gross } \\
\text { Heating } \\
\text { Value }\end{array}$ & $\begin{array}{l}\mathrm{BTU} / \mathrm{l} \\
\mathrm{b}\end{array}$ & 20107 & 20075 & 20064 & 19932 & 19908 & Calculated \\
\hline 4 & API Gravity & - & 53.4 & 52.1 & 51.7 & 48.8 & 45.6 & Calculated \\
\hline 5 & Pour Point & ${ }^{\circ} \mathrm{C}$ & $<-30$ & $<-30$ & $<-30$ & $<-30$ & $<-30$ & ASTM D 97 \\
\hline 6 & $\begin{array}{l}\text { Flash Point } \\
\text { COC }\end{array}$ & ${ }^{\circ} \mathrm{C}$ & 15,0 & 16,0 & 18,0 & 18,0 & 19,0 & ASTM D 92 \\
\hline
\end{tabular}

Explanation $=$ The result of Laboratorium examination at TMBGM (Chemical Engineering) UGM

Table 4. The Physical Characteristics of AI-PE Pyroysis Oil

Based on the result of the physical characteristic test from sample A shows the highest gross heating value that is $20.107 \mathrm{BTU} / \mathrm{lb}$, compared with other samples. The higher the heating value, it means the greater energy generated from the combustion process of these fuels. The calorific value of oil generally ranges from 18,300 - 19,800 BTU / lb. In general, the pyrolysis oil, as conducted in this research has the same range of heating value as the general oil, so it can be used for substitution alternatives. The lowest specific gravity value is indicated by the oil in sample A. Fuel oil generally has a specific gravity between 0.74-0.96. Therefore, it can be said that the all sample is still within that range. The kinematic viscosity means the amount of liquid fuel resistance to flow (the size of the shear resistance), so based on the data in Table 4, sample A has the lowest kinematic viscosity value. The flash point value for all samples is $<73^{\circ} \mathrm{C}$ so that it is classified as A class (Effendi, 2012), (Pranata, 2008),

The comparison of pyrolysis oils in this study between Al-PE plastics and other oils is shown in Table 5.

\begin{tabular}{|c|c|c|c|c|c|c|c|}
\hline \multirow[t]{2}{*}{ No } & \multirow[t]{2}{*}{ Oil Type } & \multicolumn{6}{|c|}{ Parameter } \\
\hline & & $\begin{array}{l}\text { Specific } \\
\text { gravity }\end{array}$ & $\begin{array}{l}\text { Viscosity } \\
\text { kinemati } \\
\text { c }\end{array}$ & $\begin{array}{l}\text { Gross } \\
\text { heating } \\
\text { value }\end{array}$ & $\begin{array}{l}\text { API } \\
\text { Gravity }\end{array}$ & $\begin{array}{l}\text { Pour } \\
\text { point }\end{array}$ & $\begin{array}{l}\text { Flash } \\
\text { point }\end{array}$ \\
\hline 1 & Sample A & 0,7651 & 0.667 & 20107 & 53.4 & $<-30$ & 15,0 \\
\hline 2 & Sample B & 0,7705 & 0,692 & 20075 & 52.1 & $<-30$ & 16,0 \\
\hline 3 & Sample C & 0,7724 & 0,700 & 20064 & 51.7 & $<-30$ & 18,0 \\
\hline 4 & Sample D & 0,7948 & 0,861 & 19932 & 48.8 & $<-30$ & 18,0 \\
\hline
\end{tabular}




\begin{tabular}{|c|c|c|c|c|c|c|c|}
\hline 5 & Sample E & 0,7987 & 1,064 & 19908 & 45.6 & $<-30$ & 19,0 \\
\hline 6 & Kerosene & $\begin{array}{l}0,835 \\
\text { (Maks) }\end{array}$ & $\begin{array}{l}1,2(30 \\
\text { C) }\end{array}$ & 18642,61 & 37,96 & $<-47$ & \\
\hline 7 & Solar & $\begin{array}{l}0,82- \\
0,83\end{array}$ & $1,3-1,4$ & 18470,79 & $\begin{array}{l}41,06- \\
38,98\end{array}$ & $\begin{array}{l}<-35 \\
\mathrm{~s} / \mathrm{d}<- \\
15\end{array}$ & \\
\hline 8 & Gasoline & 0,724 & 0,88 & 18900,34 & 65,03 & $<-3$ & \\
\hline 9 & HFO & 0,978 & ----- & 17654 & 13,18 & $<-10$ & \\
\hline 10 & LFO & 0,89 & $30(30 \mathrm{C})$ & 17998,28 & 27,49 & & \\
\hline
\end{tabular}

Table 5. Comparison of pyrolysis oil of Al-PE plastic waste with kerosene, gasoline, diesel, HFO and LFO

Based on comparison with gasoline, kerosene, diesel, HFO, and LFO it can be seen that oils in samples A, B, C tend to have specific gravity near gasoline, while oils in samples $\mathrm{D}$ and $\mathrm{E}$ tend to approach kerosene and diesel. The pour point value of all samples tends to approach the value of the pour point of the solar.

Particle Size and Fuel Consumption Rate on Oil Yield

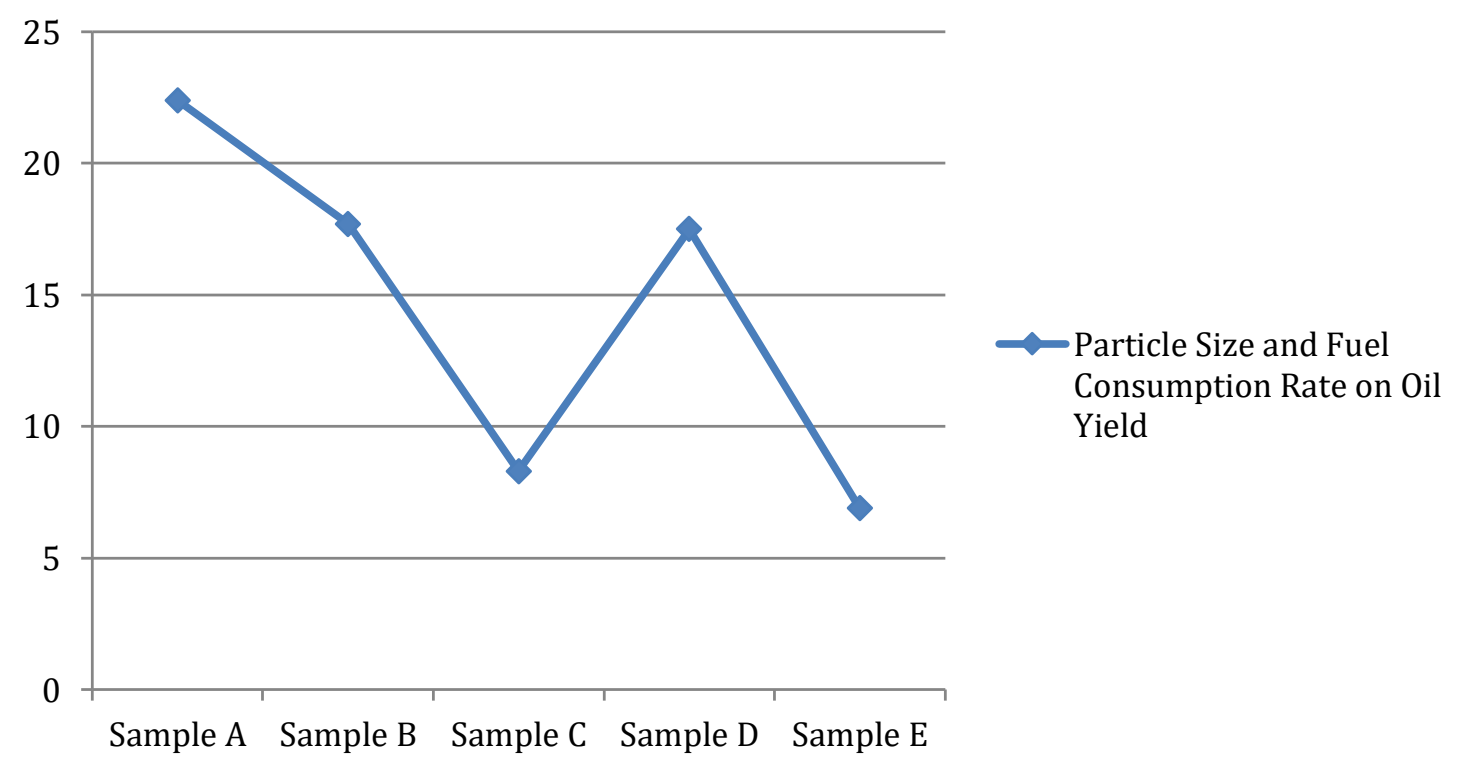

Figure 7. relationship between particle size and fuel consumption rate on oil yield and heating value

Based on the graph, sample A produces the highest Oil Yield. Sample A has smaller particle size variables and higher fuel consumption rates than others. Based on the physical characteristic test, it can be obtained that the 
smaller particle size with higher fuel consumption rate produces the oil with the highest heating value.

Particle Size and Fuel Consumption Rate on Heating Value

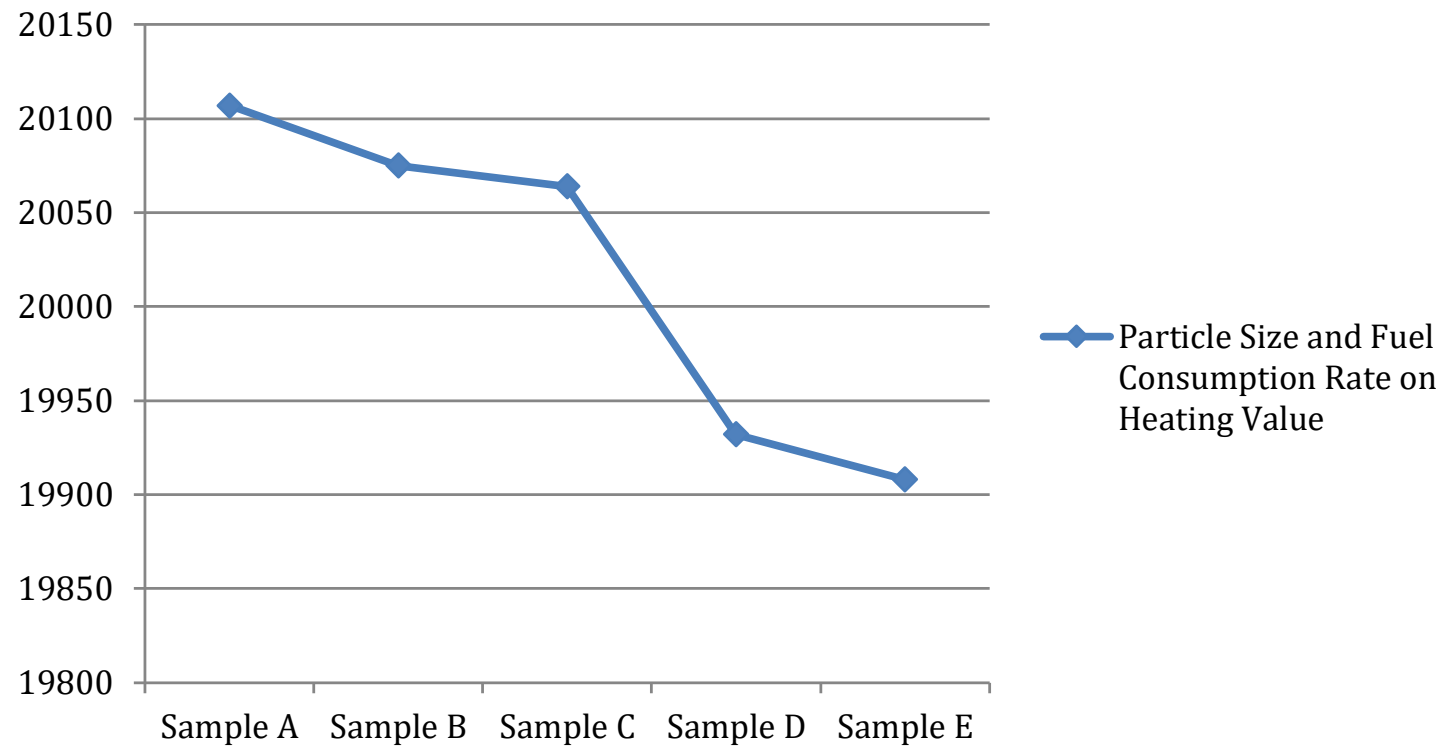

Figure 8. relationship between particle size and fuel consumption rate on heating value

Based on the graph, sample A has the highest heating value with smaller particle size variables and higher fuel consumption rate. Based on the physical characteristic test, it can be obtained that the smaller particle size with higher fuel consumption rate produces the oil with the highest heating value. This shows that the relationship between smaller particle size and higher fuel consumption rate will yield the highest yield of oil and calorific value in Al-PE plastic pyrolysis process.

\section{Conclusion}

Based on what has been done in this research, it can be drawn some conclusions as follows:

1. a. In general, Al-PE pyrolysis oil in this research has a characteristic of clear yellow color to brownish color, distinctive odor, and flammability. The physical characteristics of Al-PE pyrolysis oils are very specific, in terms of gross heating value, kinematic viscosity and specific gravity, these pyrolysis oils are close to the characteristics of diesel to gasoline. 
b. The oil yield of pyrolysis of Al-PE plastic waste is between $6.9 \% \mathrm{wt}$ to $22.4 \% \mathrm{wt}$.

2. The highest oil yield and the highest heating value obtained from sample A with the particle size of $50 \times 50 \mathrm{~mm}$ and fuel consumption rate of $4.99 \mathrm{~g} / \mathrm{min}(0.29 \mathrm{~kg} / \mathrm{h})$ per $\mathrm{kg}$ of Al-PE, for $130 \mathrm{~min}$ with material density in reactor of $27 \mathrm{~kg} / \mathrm{m} 3$.

\section{References}

[1] R. Ermawati, "Konversi Limbah Plastik sebagai Sumber Energi Alternatif," Jurnal Riset Industri, vol. 3, no. 3, pp. 257-263, 2011.

[2] Kementerian Negara Lingkungan Hidup Republik Indonesia, Statistik Persampahan Indonesia Tahun 2008, 2008.

[3] A. Purwanti and Sumarni, "Kinetika Reaksi Pirolisis Low Density Polietilena," Jurnal Teknologi, vol. 1, no. 2, pp. 135-140, 2008.

[4] A. S. Chaurasia and B. B. V., Modellimg \& Simulationof Pyrolisis of Biomass: effect of Thermal Conductiity, Reactor, Temperature and Particle Size on Product Concentration, India: Pillani, 2005.

[5] P. T. William, "Analysis and Application of Pyrolisis," Journal of Renewable Energy, vol. 29, pp. 111-128, 1994.

[6] S. Beslar and P. T. William, "The Influence of Temperature and Heating Rate on Slow Pyrolisis of Biomass," Journal of Renewable Energy, vol. 7, pp. 233-250, 1996.

[7] A. Lopez, I. d. Marco and A. A. M. F. Laresgoiti, "Influence of Time and Temperature on Pyrolisis of Plastic Wastes in Semi-Batch Reactor," Chemical Engineerung Journal, vol. 173, pp. 62-71, 2011.

[8] J. J. Park, "Characteristic of LDPE Pyrolisis," Korean Journal Chemical, vol. 19, no. 4, pp. 658-662, 2002.

[9] J. Pranata, "Pemanfaatan Sabut dan tempurung Kelapa serta Cangkang Sawit untuk Pembuatan Asap Cair," Jurusan Teknik Kimia, Fakultas Teknik Universitas Malikussaleh, Lhokseumawe, 2007.

[10] I. G. Wiratmaja, "Pengujian Karakteristik Fisika Biogasoline sebagai Bahan Bakar Alternatif Pengganti Bensin," Jurnal Ilmiah Teknik Mesin Cakra, vol. 4, no. 2, pp. 145-154, 2010. 